\title{
Stannous chloride catalyzed synthesis of Schiff bases from hydroxybenzaldehydes and determination of their antioxidant activity by ABTS and DPPH assay
}

\author{
GYANASHREE BORA, DIPANKOJ GOGOI, SUBHASMITA SAIKIA, ARCHANA PAREEK and \\ JYOTIREKHA G HANDIQUE* (D)
}

Department of Chemistry, Dibrugarh University, Dibrugarh, 786 004, Assam, India

E-mail: jghandique@ rediffmail.com

MS received 22 March 2019; revised 15 May 2019; accepted 17 May 2019

\begin{abstract}
Phenolic compounds play a very important role in human life because of their antioxidant activity which can prevent harmful diseases caused by free radicals. In the present work, we have synthesized some Schiff bases by the reaction of different hydroxybenzaldehydes and primary aromatic diamines using Stannous Chloride $\left(\mathrm{SnCl}_{2} \cdot 2 \mathrm{H}_{2} \mathrm{O}\right)$ as the catalyst. The products were characterized by FT-IR spectroscopy, GCMS and NMR spectroscopy. Furthermore, the antioxidant activity of the Schiff bases were determined by using DPPH assay and ABTS assay and the results were compared with a standard compound, trolox as well as with the parent aldehydes. The synthesized compounds were found to have better antioxidant activity than their corresponding parent aldehydes.
\end{abstract}

Keywords. Phenolic compounds; Schiff bases; antioxidant activity; ABTS assay; DPPH assay.

\section{Introduction}

In recent years, there is an escalation in research in the areas related to the prevention of diseases, especially the role of free radicals and antioxidants. The oxidant by-products of normal metabolism are either free radicals or molecular species capable of generating free radicals that are naturally produced in the body and play important roles in many normal cellular processes like cell signalling and homeostasis. ${ }^{1}$ But abnormally high concentrations of free radicals produced by ionizing radiation and other environmental toxins such as cigarette smoke, some metals and highoxygen atmospheres can be hazardous to the body and play a significant role in the damage of various biological macromolecules like cellular DNA, proteins, cell membrane, etc., leading to the development of cancer and other health conditions, including Diabetes mellitus, Hypertension, Alzheimer disease, immune-system decline, brain dysfunction, and aging of the body. Here comes the need for special substances that are proficient in blocking the activity of free radicals and thus prevent the damage of cells— - 'antioxidants.' Antioxidants can inhibit the oxidative mechanism that leads to degenerative diseases as they can terminate the deleterious chain reactions by removing the free radical intermediates and also can inhibit other oxidation reactions. In this process, they themselves do get oxidized, so antioxidants are often termed as reducing agents. ${ }^{2}$ Moreover, antioxidants have been used to prevent food rancidity as they can slow down the oxidative degradation of polyunsaturated fatty acids and also, compounds with antioxidant activity are found to possess a lot of other significant activities such as anticancer, anti-cardiovascular, antiinflammatory, etc. ${ }^{3,4}$ Mainly, phenolic compounds are one of the most important classes of bioactive antioxidants present in human diet because of their ability to scavenge free radicals as they are able to donate hydrogen atom by breaking the $\mathrm{O}-\mathrm{H}$ bond to a free radical, thereby preventing the propagation of chain at some stage in the oxidation process and finally inhibiting or retarding the entire process of oxidation. ${ }^{5}$

Among the most efficient antioxidant materials, Schiff bases are considered as one of the most

\footnotetext{
*For correspondence

Electronic supplementary material: The online version of this article (https://doi.org/10.1007/s12039-019-1645-2) contains supplementary material, which is available to authorized users.
} 
important classes of compounds. They are the condensation products of primary amines with carbonyl compounds, i.e., aldehydes or ketones; are termed as Schiff bases as they were first reported by Schiff ${ }^{6}$ in 1864 and have substantial biological activity. In Schiff bases, the oxygen of the carbonyl group is replaced by nitrogen to form the $\mathrm{C}=\mathrm{N}$ bond. The significant biological properties of Schiff bases are ascribable to the existence of the intra-molecular hydrogen bonds and the proton transfer equilibrium. In medicinal and pharmaceutical fields, Schiff bases have acquired very high significance due to a broad spectrum of biological activities like anti-inflammatory, ${ }^{7}$ analgesic,${ }^{8}$ antimicrobial, ${ }^{9}$ anticonvulsant, ${ }^{10}$ antitubercular, ${ }^{11}$ anticancer, ${ }^{12}$ antioxidant, ${ }^{13}$ anthelmintic, ${ }^{14}$ etc. The nitrogen atom of the azomethine group interferes in normal cell processes by being involved in the formation of a hydrogen bond with the active centres of cell constituents. ${ }^{15,16}$ Apart from their biological significance, Schiff bases are also used as catalysts, dyes, pigments, polymer stabilizers, intermediates in organic synthesis ${ }^{17}$ and corrosion inhibitors. ${ }^{18}$ Schiff bases are used as ligands for preparing metal complexes having a series of different structures or as intermediates for amino acid synthesis. ${ }^{19}$ They commonly co-ordinate through the $\mathrm{N}$-atom of the azomethine group or O-atom of the deprotonated phenolic group and behave as flexidentate ligands. The azomethine nitrogen of Schiff bases and other donor atoms like oxygen play a very important role in coordination chemistry. ${ }^{20}$

In our study, we synthesized phenolic aldehyde based di-imines. To synthesize the di-imines, we used 1,2-Phenylenediamine; 1,3-phenylenediamine and 1,4phenylenediamine as the primary amine substrates along with three different hydroxyl substituted aromatic aldehydes. We used a Lewis acid $\left(\mathrm{SnCl}_{2} \cdot 2 \mathrm{H}_{2} \mathrm{O}\right)$ to catalyze the reactions and then we studied their antioxidant scavenging behaviour towards ABTS (2, 2'azinobis-3-ethylbenzothiazoline-6-sulfonic acid) radical and DPPH (1,1-diphenyl-2-picrylhydrazyl) radical.

\section{Experimental}

2-hydroxybenzaldehyde was purchased from 'MERCK', 3-hydroxybenzaldehyde from 'Sigma Aldrich', 4hydroxybenzaldehyde from SRL (Sisco Research Laboratory). 1,2-Phenylenediamine; 1,3-phenylenediamine and 1,4phenylenediamine were purchased from TCI (Tokyo Chemical Industry Co., Ltd). $\mathrm{SnCl}_{2} \cdot 2 \mathrm{H}_{2} \mathrm{O}$ was purchased from BDH. ABTS and DPPH were purchased from Sigma Aldrich. Methanol was of LR grade and purchased from 'Rankem' and dichloromethane was purchased from 'SRL' and both were distilled before use.
The infrared spectra of the Schiff bases were recorded within the range $400-4000 \mathrm{~cm}^{-1}$ using Shimadzu FT-IR spectrophotometer, model: Prestige 21. ${ }^{1} \mathrm{HNMR}$ spectra of the Schiff bases were recorded with JEOL, $400 \mathrm{MHz}$ and Bruker Avance III $500 \mathrm{MHz}$ FT-NMR spectrophotometer using DMSO- $\mathrm{d}_{6}$ as the solvent and TMS as the internal standard. The mass spectra of the compounds were recorded using Agilent GC-7820A/MS5975 analyzer in methanol. The ABTS and DPPH radical absorptions were recorded with UVvisible spectrophotometer, Hitachi model: U-3900H.

For the preparation of the Schiff bases, a dry round bottom flask $(50 \mathrm{~mL})$ was equipped with an efficient magnetic stirrer. $0.1 \mathrm{mmol}$ of $\mathrm{SnCl}_{2} \cdot 2 \mathrm{H}_{2} \mathrm{O}$ was slowly added to the mixture of $2 \mathrm{mmol}$ of an aldehyde and $1 \mathrm{mmol}$ of the primary amine dissolved in dichloromethane. The reaction mixture was allowed to stir at room temperature. The progress of the reaction was monitored by TLC. After the completion of the reaction, the solid products were separated from the reaction mixture by filtration and washed with dichloromethane and water. The desired Schiff bases were synthesized according to the reaction schemes showed in Table 1.

\subsection{DPPH assay}

The antioxidant activities of the synthesized imines were measured on the basis of the scavenging of the stable 1,1diphenyl-2-picrylhydrazyl (DPPH) free radical according to the method described by Brand-Williams et al. ${ }^{21}$ with slight modification. The stock solution of DPPH free radical was prepared by dissolving $0.004 \mathrm{~g}$ in $10 \mathrm{~mL}$ of methanol in dark. For each different concentrations of imine $(2,4,6,8$ and $10 \mathrm{mmol} / \mathrm{L}$ ), blank solutions were prepared by adding $200 \mu \mathrm{L}$ of DPPH free radical stock solution in $3 \mathrm{~mL}$ of methanol and their absorbance were measured at $517 \mathrm{~nm}$. Then, in each blank solution, $100 \mu \mathrm{L}$ of the imine with different concentration $(2,4,6,8$ and $10 \mathrm{mmol} / \mathrm{L})$ was added and kept in dark for $30 \mathrm{~min}$. After $30 \mathrm{~min}$ their absorbance were measured at $517 \mathrm{~nm}$. By plotting the values of percentage inhibition as the abscissa and the concentration as the ordinate, we calculated the $\mathrm{IC}_{50}$ values for each of the samples. The $\mathrm{IC}_{50}$ value represents the concentration of an antioxidant or inhibitor required to reduce the concentration of the free radicals by half of their initial concentration measured at $\lambda_{\max }=517 \mathrm{~nm}$.

\subsection{ABTS assay}

To determine the antioxidant activities of the synthesized Schiff bases, we followed the ABTS method of Arnao et al. ${ }^{22}$ with a little amendment. The stock solutions were prepared as $7 \mathrm{mM}$ ABTS solution and $2.4 \mathrm{mM}$ potassium persulfate solution. Then the working solution for ABTS assay was prepared by mixing both the stock solutions of ABTS and potassium persulfate in equal quantities and allowing them to react for $14-16 \mathrm{~h}$ at room temperature in dark. The solution was then diluted by mixing $100 \mu \mathrm{L}$ ABTS solution with $6 \mathrm{~mL}$ methanol to obtain an absorbance around $0.706 \pm 0.01$ units at $734 \mathrm{~nm}$ using a UV spectrophotometer. We prepared 
fresh ABTS solution for each assay. $100 \mu \mathrm{L}$ of the solutions (prepared in methanol) of each compound, as well as trolox (used as a standard) at four different concentrations (2, 4, 6, 8 $10 \mathrm{mmol} / \mathrm{L}$ of methanol), were allowed to react with $2.5 \mathrm{~mL}$ of the ABTS solution. The absorbance was observed at $734 \mathrm{~nm}$ after 6 min for each sample for each concentration.

The percentage inhibitions of the synthesized products for both the methods were calculated using the following formula-

$\%$ Inhibition $=\left(A_{B}-A_{S}\right) / A_{B} \times 100$

Where, $A_{B}$ is the absorbance of the ABTS/DPPH solution without sample and $A_{S}$ is the absorbance of ABTS/ DPPH solution with the sample. The percentage inhibition was plotted against concentration and a straight line is obtained. From this graph we have calculated the $\mathrm{IC}_{50}$ values of the Schiff bases; that is, the amount of antioxidant Schiff bases necessary to decrease the $50 \%$ of the initial ABTS or DPPH radical concentration.

\section{Results and Discussion}

All the synthesized compounds were crystalline solids and found to be soluble in methanol and insoluble in dichloromethane. The reaction scheme, the time period of reactions, their percentage yields and the name of the synthesized products are mentioned in Table 1 .

\subsection{Characterization}

The FT-IR Spectra of all the compounds gave characteristic bands for $\mathrm{C}=\mathrm{N}$ stretching whereas the characteristic bands for carbonyl group of the aldehydes and the primary amino groups present in the starting materials did not occur in the IR spectra of each of the nine compounds, giving rise to the inference that the substrates were successfully converted into the desired di-Schiff bases. No characteristic peaks were observed for protons of the aldehyde or the amino group in the ${ }^{1} \mathrm{H}-\mathrm{NMR}$ spectra, which affirms the formation of the desired dischiff base products and also by the ${ }^{13} \mathrm{C}$-NMR spectra of the compounds, the formation of imine bonds were confirmed. In the GCMS analysis of the compounds, the existence of molecular ion peak $\left(\mathrm{M} \cdot{ }^{+}\right)$with $\mathrm{m} / \mathrm{z}$ value of 316.1 confirmed the formation of the desired products.

\section{Schiff Base 1:}

FT-IR $\left(\mathrm{KBr}, \mathrm{cm}^{-1}\right)$ : 3571.36 (Phenolic OH), 3108.42 (Aromatic C-H), 1612.56 (aromatic $\mathrm{C}=\mathrm{N}$ ), 1572.051465.96 (Aromatic $\mathrm{C}=\mathrm{C}$ ); ${ }^{1} \mathrm{H}$ NMR (DMSO- $\mathrm{d}_{6} ; \delta$, ppm):8.55 (singlet, $\mathrm{N}=\mathrm{C}-\mathrm{H}$ ), 5.21 (singlet, $\mathrm{O}-\mathrm{H}$ ), 7.306.56 (multiplet, Aromatic protons); ${ }^{13} \mathrm{C}$ NMR $\left(\mathrm{DMSO}_{6} ; \delta, \mathrm{ppm}\right): 162.41$ (Aromatic $\left.\mathrm{C}=\mathrm{N}\right), 161.01$
$(\mathrm{C}-\mathrm{OH}), \quad 122.21 \quad$ (Aromatic $\mathrm{C}-\mathrm{N}) ; \mathrm{GCMS}(\mathrm{m} / \mathrm{z})$ : 316.1 $\left(\mathrm{M}^{+}\right)$

\section{Schiff Base 2:}

FT-IR $\left(\mathrm{KBr}, \mathrm{cm}^{-1}\right)$ : 3209.69 (Phenolic OH), 3039.94 (Aromatic C-H), 1607.74 (Aromatic C=N), 1514.191457.28 (Aromatic $\mathrm{C}=\mathrm{C}$ ); ${ }^{1} \mathrm{H}$ NMR DMSO-d $\mathrm{d}_{6} ; \delta, \mathrm{ppm}$ ): 8.18 (singlet, $\mathrm{N}=\mathrm{C}-\mathrm{H}$ ), 5.42 (singlet, $\mathrm{O}-\mathrm{H}$ ), 7.66-6.61 (multiplet, Aromatic protons); ${ }^{13} \mathrm{CNMR}$ (DMSO- $\mathrm{d}_{6} ; \delta$, ppm): $161.02(\mathrm{C}=\mathrm{N}), 160.19(\mathrm{C}-\mathrm{OH}), 153.87$ (aromatic $\mathrm{C}-\mathrm{N}) ; \operatorname{GCMS}(\mathrm{m} / \mathrm{z}): 316.1\left(\mathrm{M}^{+}{ }^{+}\right)$

\section{Schiff Base 3:}

FT-IR $\left(\mathrm{KBr}, \mathrm{cm}^{-1}\right)$ : 3229.04 (Phenolic OH), 3062.96 (Aromatic C-H), 1602.85 (Aromatic C=N), 1498.691458.18 (Aromatic $\mathrm{C}=\mathrm{C}$ ); ${ }^{1} \mathrm{H}$ NMR (DMSO- $\mathrm{d}_{6} ; \delta$, ppm): 8.24 (singlet, $\mathrm{N}=\mathrm{C}-\mathrm{H}$ ), 5.35(singlet, $\mathrm{O}-\mathrm{H}$ ), 7.766.92 (multiplet, Aromatic protons); ${ }^{13} \mathrm{C}$ NMR $\left(\mathrm{DMSO}-\mathrm{d}_{6} ; \delta, \mathrm{ppm}\right): 163.61(\mathrm{C}=\mathrm{N}), 160.01(\mathrm{C}-\mathrm{OH})$, 142.59 (aromatic C-N); GCMS(m/z): 316.1 $\left(\mathrm{M}^{+}{ }^{+}\right.$)

\section{Schiff Base 4:}

FT-IR $\left(\mathrm{KBr}, \mathrm{cm}^{-1}\right)$ : 3327.21 (Phenolic OH), 3024.38 (Aromatic C-H), 1603.05 (Aromatic C=N), 1504.481435.04 (Aromatic $\mathrm{C}=\mathrm{C}$ ) ${ }^{1} \mathrm{HNMR}\left(\mathrm{DMSO}-\mathrm{d}_{6} ; \delta, \mathrm{ppm}\right.$ ): 8.42 (singlet, $\mathrm{N}=\mathrm{C}-\mathrm{H}$ ), 5.44 (singlet, $\mathrm{O}-\mathrm{H}$ ), 7.68-6.33 (multiplet, Aromatic protons); ${ }^{13} \mathrm{CNMR}\left(\mathrm{DMSO}-\mathrm{d}_{6} ; \delta\right.$, ppm): $161.80(\mathrm{C}=\mathrm{N}), 158.19(\mathrm{C}-\mathrm{OH}), 122.95$ (Aromatic $\mathrm{C}-\mathrm{N}) ; \operatorname{GCMS}(\mathrm{m} / \mathrm{z}): 316.1\left(\mathrm{M}^{+}\right)$

\section{Schiff Base 5:}

FT-IR $\left(\mathrm{KBr}, \mathrm{cm}^{-1}\right)$ : 3354.21 (Phenolic OH), 3076.48 (Aromatic C-H) 1600.92 (Aromatic C=N), 1500.621486.38 (Aromatic C $=\mathrm{C}$ ); ${ }^{1} \mathrm{HNMR}\left(\mathrm{DMSO}-\mathrm{d}_{6} ; \delta, \mathrm{ppm}\right)$ : 8.36 (singlet, $\mathrm{N}=\mathrm{C}-\mathrm{H}$ ), 5.21(singlet, $\mathrm{O}-\mathrm{H}$ ), 7.58-6.69 (multiplet, Aromatic protons); ${ }^{13} \mathrm{CNMR}\left(\mathrm{DMSO}_{-} \mathrm{d}_{6} ; \delta\right.$, ppm): $163.97(\mathrm{C}=\mathrm{N}), 157.66(\mathrm{C}-\mathrm{OH}), 153.97$ (Aromatic $\mathrm{C}-\mathrm{N}) ; \operatorname{GCMS}(\mathrm{m} / \mathrm{z}): 316.1\left(\mathrm{M} \cdot{ }^{+}\right)$

\section{Schiff Base 6:}

FT-IR $\left(\mathrm{KBr}, \mathrm{cm}^{-1}\right)$ : 3215.37 (Phenolic OH), 3018.04 (Aromatic C-H), 1660.00 (Aromatic $\mathrm{C}=\mathrm{N}$ ), 1593.201443.17 (Aromatic C $=\mathrm{C}) ;{ }^{1} \mathrm{HNMR}\left(\mathrm{DMSO}-\mathrm{d}_{6} ; \delta\right.$, ppm): 8.51 (singlet, $\mathrm{N}=\mathrm{C}-\mathrm{H}$ ), 5.20 (singlet, $\mathrm{O}-\mathrm{H}$ ), 7.79-6.88 (multiplet, Aromatic protons); ${ }^{13} \mathrm{CNMR}\left(\mathrm{DMSO}-\mathrm{d}_{6} ; \delta\right.$, ppm): $163.15(\mathrm{C}=\mathrm{N}), 158.88(\mathrm{C}-\mathrm{OH}), 142.13$ (aromatic $\mathrm{C}-\mathrm{N}) ; \mathrm{GCMS}(\mathrm{m} / \mathrm{z}): 316.1\left(\mathrm{M} \cdot{ }^{+}\right)$

\section{Schiff Base 7:}

FT-IR $\left(\mathrm{KBr}, \mathrm{cm}^{-1}\right)$ : 3500.80 (Phenolic OH), 3058.57 (Aromatic C-H), 1610.56 (Aromatic $\mathrm{C}=\mathrm{N}$ ), 1496.781462.04 (Aromatic $\mathrm{C}=\mathrm{C}) ;{ }^{1} \mathrm{H}$ NMR $\left(\mathrm{DMSO} \mathrm{d}_{6} ; \delta, \mathrm{ppm}\right)$ : 8.03 (singlet, $\mathrm{N}=\mathrm{C}-\mathrm{H}$ ), 5.40 (singlet, $\mathrm{O}-\mathrm{H}$ ), 7.65-6.58 (multiplet. Aromatic protons); ${ }^{13} \mathrm{C}$ NMR (DMSO- $\mathrm{d}_{6} ; \delta$, ppm): $163.07(\mathrm{C}=\mathrm{N}), 158.98(\mathrm{C}-\mathrm{OH}), 120.96$ (aromatic $\mathrm{C}-\mathrm{N}) ; \operatorname{GCMS}(\mathrm{m} / \mathrm{z}): 316.1\left(\mathrm{M} \cdot{ }^{+}\right)$ 
Table 1. Schemes of synthesis of the desired Schiff bases catalysed by Stannous Chloride, their percentage yields and the IUPAC names of the products formed.

\begin{tabular}{|c|c|c|c|}
\hline Compounds & Schemes of synthesis & $\begin{array}{l}\text { Yield } \\
(\%)\end{array}$ & $\begin{array}{c}\text { IUPAC Name of } \\
\text { product }\end{array}$ \\
\hline 1 & 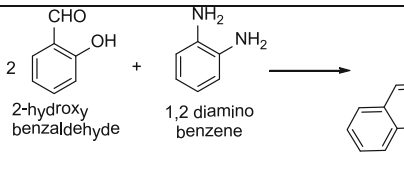 & 77.5 & $\begin{array}{l}\text { 2,2'-((1E,1'E)-(1,2- } \\
\text { phenylenebis(azanylylide } \\
\text { ne))bis(methanylylidene)) } \\
\text { diphenol }\end{array}$ \\
\hline 2 & 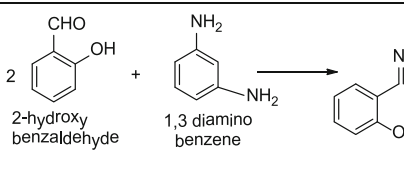 & 86.9 & $\begin{array}{l}\text { 2,2'-((1E,1'E)-(1,3- } \\
\text { phenylenebis(azanylylide } \\
\text { ne) }) \text { bis(methanylylidene })) \\
\text { diphenol }\end{array}$ \\
\hline 3 & $\begin{array}{l}\text { 2-hydroxy } \\
\text { benzaldehyde }\end{array}$ & 87.7 & $\begin{array}{l}\text { 2,2'-((1E,1'E)-(1,4- } \\
\text { phenylenebis(azanylylide } \\
\text { ne))bis(methanylylidene) }) \\
\text { diphenol }\end{array}$ \\
\hline 4 & 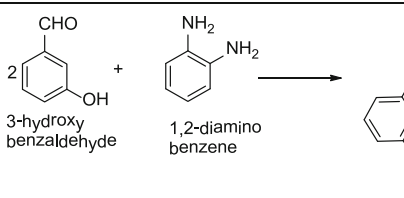 & 76.5 & $\begin{array}{l}\text { 3,3'-((1E,1'E)-(1,2- } \\
\text { phenylenebis(azanylylide } \\
\text { ne))bis(methanylylidene) }) \\
\text { diphenol }\end{array}$ \\
\hline 5 & 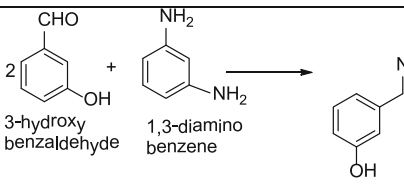 & 78.4 & $\begin{array}{l}\text { 3,3'-((1E,1'E)-(1,3- } \\
\text { phenylenebis(azanylylide } \\
\text { ne))bis(methanylylidene)) } \\
\text { diphenol }\end{array}$ \\
\hline 6 & 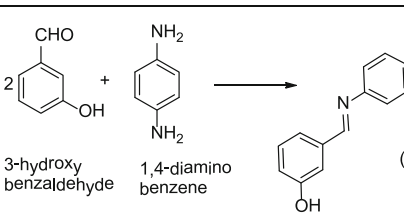 & 82.5 & $\begin{array}{l}\text { 3,3'-((1E,1'E)-(1,4- } \\
\text { phenylenebis(azanylylide } \\
\text { ne))bis(methanylylidene) }) \\
\text { diphenol }\end{array}$ \\
\hline 7 & 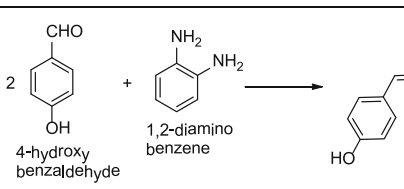 & 84.3 & $\begin{array}{l}\text { 4,4'-((1E,1'E)-(1,2- } \\
\text { phenylenebis(azanylylide } \\
\text { ne))bis(methanylylidene)) } \\
\text { diphenol }\end{array}$ \\
\hline 8 & - & 80.5 & $\begin{array}{l}\text { 4,4'-((1E,1'E)-(1,3- } \\
\text { phenylenebis(azanylylide } \\
\text { ne))bis(methanylylidene)) } \\
\text { diphenol }\end{array}$ \\
\hline 9 & 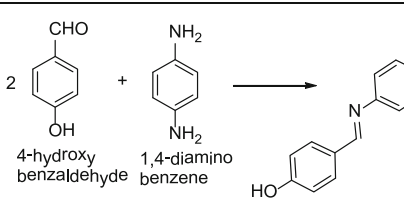 & 82.4 & $\begin{array}{l}\text { 4,4'-((1E,1'E)-(1,4- } \\
\text { phenylenebis(azanylylide } \\
\text { ne))bis(methanylylidene)) } \\
\text { diphenol }\end{array}$ \\
\hline
\end{tabular}

*The molar ratio of aldehyde:amine is taken as 2:1 in all the reactions for the formation of the desired di-schiff bases and all the reactions are allowed to run for $6 \mathrm{~h}$. 


\section{Schiff Base 8:}

FT-IR $\left(\mathrm{KBr}, \mathrm{cm}^{-1}\right)$ : 3512.37 (Phenolic OH), 3223.01 (Aromatic C-H), 1633.71 (Aromatic $\mathrm{C}=\mathrm{N}$ ), 1504.481483.76 (Aromatic $\mathrm{C}=\mathrm{C}$ ); ${ }^{1} \mathrm{H}$ NMR (DMSO- $\mathrm{d}_{6} ; \delta$, ppm): 8.48 (singlet, $\mathrm{N}=\mathrm{C}-\mathrm{H}$ ), 5.35 (singlet, $\mathrm{O}-\mathrm{H}$ ), 7.76-6.59 (multiplet, Aromatic protons); ${ }^{13} \mathrm{C} \mathrm{NMR}$ $\left(\mathrm{DMSO}-\mathrm{d}_{6} ; \delta, \mathrm{ppm}\right): 163.62(\mathrm{C}=\mathrm{N}), 160.01(\mathrm{C}-\mathrm{OH})$, 154.83 (aromatic C-N); GCMS(m/z): 316.1(M. ${ }^{+}$)

\section{Schiff Base 9:}

FT-IR $\left(\mathrm{KBr}, \mathrm{cm}^{-1}\right)$ : 3491.16 (Phenolic OH), 3290.56 (Aromatic C-H), 1649.14 (Aromatic C=N), 1536.841458.18 (Aromatic $\mathrm{C}=\mathrm{C}) ;{ }^{1} \mathrm{H}$ NMR $\left(\mathrm{DMSO}-\mathrm{d}_{6} ; \delta, \mathrm{ppm}\right.$ ) 8.52 (singlet, $\mathrm{N}=\mathrm{C}-\mathrm{H}$ ), 5.33 (singlet, $\mathrm{O}-\mathrm{H}$ ), 7.80-6.88 (multiplet, Aromatic protons); ${ }^{13} \mathrm{C}$ NMR (DMSO- $\mathrm{d}_{6} ; \delta$, ppm): $161.80(\mathrm{C}=\mathrm{N}), 160.8(\mathrm{C}-\mathrm{OH}), 148.19$ (aromatic $\mathrm{C}-\mathrm{N}) ; \operatorname{GCMS}(\mathrm{m} / \mathrm{z}): 316.1\left(\mathrm{M}^{+}{ }^{+}\right)$

\subsection{Determination of antioxidant activity}

The antioxidant activities of the hydroxyl di-Schiff bases and the parent aldehydes were evaluated by the ABTS and DPPH radical scavenging assay. Since the compounds are substituted with the phenolic $\mathrm{OH}$ groups, they show considerable radical scavenging activities. The working out of the radical scavenging capacity is based on the UV absorbance spectra of the compounds after reaction with the ABTS radical cation and DPPH radical. In our experiment, Trolox was taken as the standard for comparing the radical scavenging activities. Results are presented in Table 2.

3.2a DPPH radical scavenging assay: The observations found by using DPPH Radical Scavenging Assay are presented in Table 2 and Figures 1, 2 and 3.

It is observed that the $\mathrm{IC}_{50}$ values of the synthesized compounds decrease in the following order: $1>5>$ $6>4>2>8>7>3>9$. We know that the smaller the $\mathrm{IC}_{50}$ value, greater is the antioxidant activity of the compound. So, the order of Antioxidant activity is $9>3>7>8>2>4>6>5>1$.

From the calculation of the $\mathrm{IC}_{50}$, it is obvious that the $\mathrm{IC}_{50}$ values of the parent aldehydes are greater than the synthesized products. Therefore, we can say that the synthesized compounds have better antioxidant activity than their corresponding parent aldehydes. However, there is an exception to the compound 1 showing higher $\mathrm{IC}_{50}$ value and lower percentage inhibition than all the other synthesized compounds, and thus it is found to have the lowest antioxidant activity. This may be attributed to the possible intra-molecular $\mathrm{H}$ bonding present in the compound. The Schiff bases formed using meta isomers of either the aldehyde or the amine are found to have less antioxidant activity compared to the ones formed using ortho or para isomers of both the substrates (except compound 1). This may be due to the possibility of a lesser number of resonance structures in meta-isomer compared to para and ortho isomer. Thus, compound 5, the condensation product of meta-hydroxybenzaldehyde and 1,3-phenylenediamine is found to have the second highest $\mathrm{IC}_{50}$ value and thus the second lowest antioxidant activity.

Among the parent aldehydes, p-hydroxybenzaldehyde is found to have the highest antioxidant activity and the ortho isomer is found to have the lowest antioxidant activity. This also may be attributed to the intramolecular H-bonding present in the orthohydroxybenzaldehyde. Compound 9, 3 and 7 are found to have very low $\mathrm{IC}_{50}$ values compared to the standard compound Trolox which is a very good antioxidant. So, we can say that these compounds can work as much better antioxidants than not only their parent aldehydes but also the standard Trolox. Compound 9, synthesized from, both the para isomers of aldehyde and amine is found to have the highest percentage inhibition and antioxidant activity. This may be due to the presence of a higher number of resonance structures compared to the compounds synthesized from meta-isomers, as well as due to the absence of intramolecular $\mathrm{H}$-bonding and steric repulsion present in ortho-isomers.

3.2b ABTS radical scavenging assay: The observations of the experiments conducted to determine the antioxidant activities of the synthesized compounds by ABTS assay are presented in Table 2 and Figures 4, 5 and 6 . It is observed that the $\mathrm{IC}_{50}$ values of the synthesized compounds decrease in the following order: $1>5>4>6>2>8>7>3>9$. We know that the smaller the $\mathrm{IC}_{50}$ value, greater is the antioxidant activity of the compound. So, the order of Antioxidant activity is $9>3>7>8>2>6>4>5>1$. From the calculation of $\mathrm{IC}_{50}$ values, we can conclude that synthesized compounds have better antioxidants activity than their corresponding parent aldehydes.

Similar to DPPH Assay, compound I is found to have the highest $\mathrm{IC}_{50}$ value and thus the lowest antioxidant activity followed by compound 5 . Compounds synthesized from the meta-isomers of the substrates are found to be weaker antioxidants than the products synthesized from the ortho and para isomer (except compound 1). On the other hand, compound 9 is found to have the highest percentage inhibition and thus the strongest antioxidant activity among all the compounds followed by compound 3. By following ABTS Assay calculations, we have seen that Compounds 9, 3, 7, 8, 2 and 6 are found 
Table 2. Percentage inhibition and $\mathrm{IC}_{50}$ values of synthesized Schiff bases by ABTS assay and DPPH assay.

\begin{tabular}{|c|c|c|c|c|c|}
\hline \multirow[t]{2}{*}{ Compound } & \multirow[t]{2}{*}{ Concentration (mM) } & \multicolumn{2}{|l|}{$\underline{\text { DPPH assay }}$} & \multicolumn{2}{|l|}{ ABTS assay } \\
\hline & & $\%$ inhibition & $\mathrm{IC}_{50}$ Value & $\%$ inhibition & $\mathrm{IC}_{50}$ Value \\
\hline \multirow[t]{5}{*}{ Compound 1} & 2 & 1.698 & 95.477 & 10.358 & 43.468 \\
\hline & 4 & 3.043 & & 12.632 & \\
\hline & 6 & 4.015 & & 14.886 & \\
\hline & 8 & 4.948 & & 16.364 & \\
\hline & 10 & 5.897 & & 17.987 & \\
\hline \multirow[t]{5}{*}{ Compound 2} & 2 & 1.237 & 53.554 & 20.12 & 11.471 \\
\hline & 4 & 3.252 & & 26.467 & \\
\hline & 6 & 4.8 & & 32.563 & \\
\hline & 8 & 6.905 & & 39.04 & \\
\hline & 10 & 8.871 & & 45.432 & \\
\hline \multirow[t]{5}{*}{ Compound 3} & 2 & 19.937 & 28.466 & 30.829 & 4.390 \\
\hline & 4 & 22.523 & & 44.444 & \\
\hline & 6 & 24.925 & & 62.404 & \\
\hline & 8 & 26.922 & & 82.914 & \\
\hline & 10 & 29.026 & & 102.799 & \\
\hline \multirow{5}{*}{ Compound 4} & 2 & 6.496 & 59.587 & 12.576 & 29.176 \\
\hline & 4 & 8.234 & & 14.568 & \\
\hline & 6 & 10.047 & & 17.287 & \\
\hline & 8 & 11.206 & & 20.479 & \\
\hline & 10 & 12.531 & & 23.565 & \\
\hline \multirow{5}{*}{ Compound 5} & 2 & 1.197 & 80.682 & 8.262 & 38.152 \\
\hline & 4 & 2.285 & & 9.823 & \\
\hline & 6 & 4.001 & & 13 & \\
\hline & 8 & 4.936 & & 14.993 & \\
\hline & 10 & 6.076 & & 17.29 & \\
\hline \multirow[t]{5}{*}{ Compound 6} & 2 & 6.246 & 62.320 & 11.724 & 20.288 \\
\hline & 4 & 7.985 & & 17.67 & \\
\hline & 6 & 9.87 & & 20.318 & \\
\hline & 8 & 10.835 & & 24.748 & \\
\hline & 10 & 12.031 & & 28.736 & \\
\hline \multirow[t]{5}{*}{ Compound 7} & 2 & 2.435 & 29.910 & 24.5 & 5.551 \\
\hline & 4 & 4.855 & & 40.88 & \\
\hline & 6 & 8.274 & & 54.66 & \\
\hline & 8 & 12.205 & & 66.368 & \\
\hline & 10 & 16.012 & & 78.618 & \\
\hline \multirow[t]{5}{*}{ Compound 8} & 2 & 7.113 & 52.667 & 27.7 & 7.287 \\
\hline & 4 & 9.125 & & 37.803 & \\
\hline & 6 & 10.344 & & 43.387 & \\
\hline & 8 & 12.255 & & 52.95 & \\
\hline & 10 & 14 & & 61.527 & \\
\hline \multirow{5}{*}{ Compound 9} & 2 & 12.527 & 17.594 & 30.184 & 3.552 \\
\hline & 4 & 16.752 & & 58.911 & \\
\hline & 6 & 22.321 & & 76.562 & \\
\hline & 8 & 26.84 & & 99.37 & \\
\hline & 10 & 31.624 & & 121 & \\
\hline \multirow[t]{5}{*}{ 2-hydroxybenzaldehyde (PA1) } & 2 & 5.954 & 134.276 & 2 & 59.823 \\
\hline & 4 & 6.553 & & 4 & \\
\hline & 6 & 7.385 & & 5.6 & \\
\hline & 8 & 7.95 & & 7.14 & \\
\hline & 10 & 8.588 & & 8.7 & \\
\hline \multirow[t]{5}{*}{ 3-hydroxybenzaldehyde (PA2) } & 2 & 6.393 & 94.126 & 6 & 40.529 \\
\hline & 4 & 7.06 & & 8 & \\
\hline & 6 & 8.03 & & 11 & \\
\hline & 8 & 9.09 & & 12.85 & \\
\hline & 10 & 10.128 & & 15 & \\
\hline \multirow{2}{*}{ 4-hydroxybenzaldehyde (PA3) } & 2 & 2.991 & 65.612 & 17.9 & 27.444 \\
\hline & 4 & 4.593 & & 21.1 & \\
\hline
\end{tabular}


Table 2. (contd.)

\begin{tabular}{|c|c|c|c|c|c|}
\hline \multirow[t]{2}{*}{ Compound } & \multirow[t]{2}{*}{ Concentration (mM) } & \multicolumn{2}{|l|}{ DPPH assay } & \multicolumn{2}{|l|}{ ABTS assay } \\
\hline & & $\%$ inhibition & $\mathrm{IC}_{50}$ Value & $\%$ inhibition & $\mathrm{IC}_{50}$ Value \\
\hline & 6 & 6.051 & & 23.33 & \\
\hline & 8 & 7.481 & & 24.95 & \\
\hline & 10 & 8.932 & & 28.5 & \\
\hline \multirow[t]{5}{*}{ Trolox } & 2 & 7.972 & 43.244 & 5.718 & 30.302 \\
\hline & 4 & 10.01 & & 9.823 & \\
\hline & 6 & 12.048 & & 13 & \\
\hline & 8 & 14.086 & & 15.565 & \\
\hline & 10 & 16.124 & & 18.29 & \\
\hline
\end{tabular}

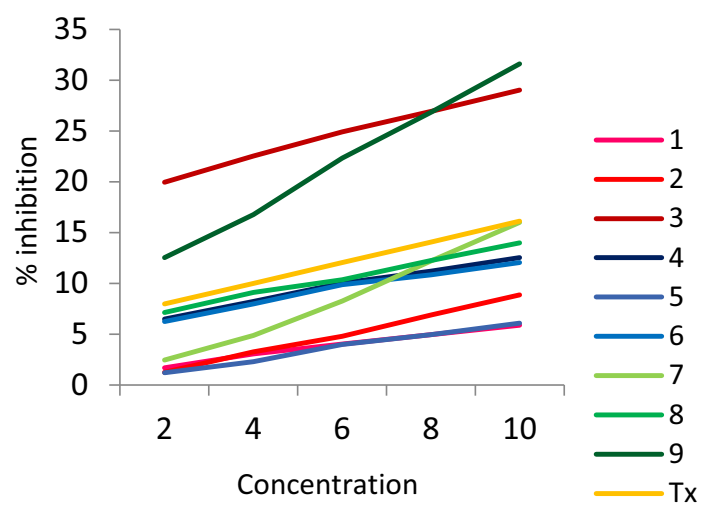

Figure 1. Percentage Inhibition Vs Concentration $(\mathrm{mmol} / \mathrm{L})$ of the Schiff Bases and Trolox by using DPPH assay.

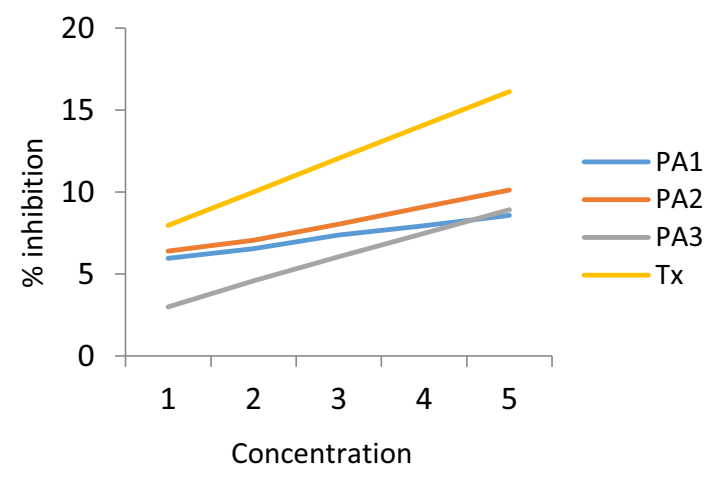

Figure 2. Percentage Inhibition Vs Concentration of the parent aldehydes and trolox ( $\mathrm{mmol} / \mathrm{L})$ by using DPPH assay.

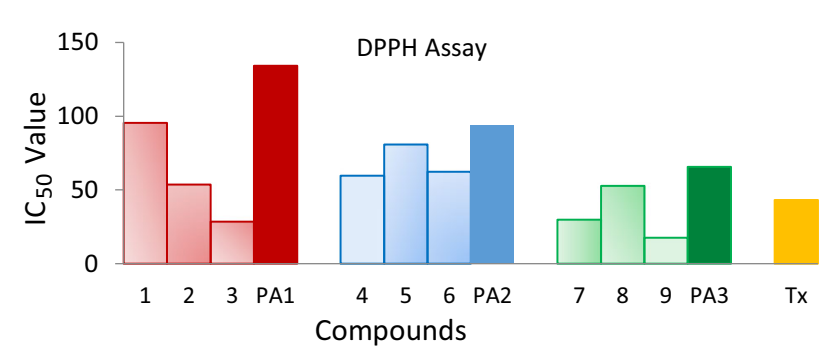

Figure 3. $\mathrm{IC}_{50}$ Values of the Phenolic Schiff Bases in comparison to their parent aldehydes and Trolox by using DPPH Assay.

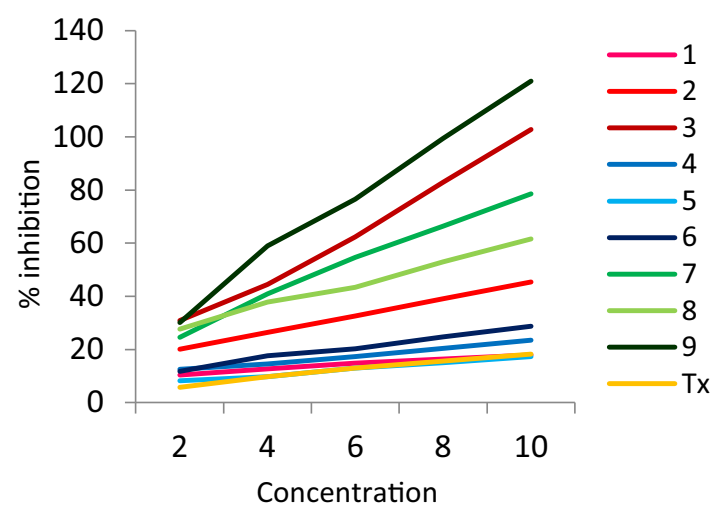

Figure 4. Percentage Inhibition Vs Concentration $(\mathrm{mmol} / \mathrm{L})$ of the Schiff Bases and Trolox by using ABTS assay.

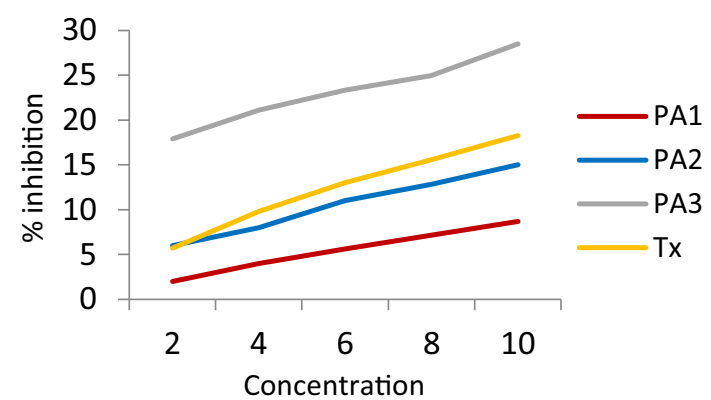

Figure 5. Percentage Inhibition Vs Concentration $(\mathrm{mmol} / \mathrm{L})$ of the parent aldehydes and Trolox by using ABTS assay.

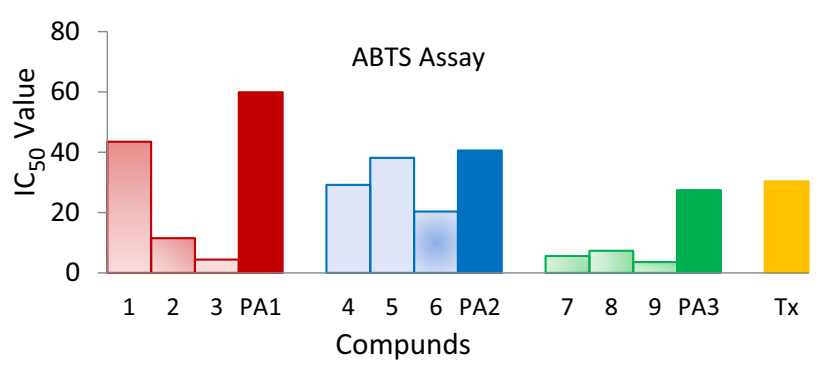

Figure 6. $\mathrm{IC}_{50}$ Values of the Phenolic Schiff Bases in comparison to their parent aldehydes and Trolox by using ABTS Assay. 
to have very less $\mathrm{IC}_{50}$ values and thus higher antioxidant activity compared to the standard compound Trolox.

\section{Conclusions}

In conclusion, we have synthesized a total of nine Schiff bases and studied their antioxidant activity by using DPPH and ABTS assay in order to compare the results obtained by both the two methods. The formation of the di-Schiff bases took considerable time because of the steric hindrance of the aromatic rings. All the synthesized products are found to have greater antioxidant activity than their corresponding parent aldehydes. This result may be attributed to the formation of the $\mathrm{C}=\mathrm{N}$ bonds and increase in conjugation in the products compared to their parent aldehydes. Schiff bases formed from the ortho- or para-isomers of the substrates (except compound 1) are found to have better antioxidant activity compared to the ones formed from meta-isomers by using both the ABTS and DPPH Assay. Schiff base 9 is found to have the strongest antioxidant activity due to possibility of having higher number of resonance structures and lowest steric repulsion well as absence of intramolecular hydrogen bonding whereas Schiff base 1 is found to have the lowest antioxidant activity which may be due to the presence of steric repulsion or intramolecular $\mathrm{H}$ bonding leading to toughest removal of the phenolic $\mathrm{H}$-atom.

\section{Supplementary Information (SI)}

General experimental procedure, IR, ${ }^{1} \mathrm{HNMR}$ and $13 \mathrm{CNMR}$ spectra for all compounds and graphs for calculation of IC50 values using DPPH and ABTS assay are available at www. ias.ac.in/chemsci.

\section{Acknowledgements}

The authors gratefully acknowledge the University Grant Commission's Basic Scientific Research programme for providing Research Fellowship for Meritorious Students (UGCBSR-RFSMS fellowship) to GB and UGC-SAP-DRS and DST-FIST for financial support.

\section{References}

1. Valko M, Leibfritz D, Moncol J, Cronin M T, Mazur M and Telser J 2007 Free radicals and antioxidants in normal physiological functions and human disease Int. J. Biochem. Cell Biol. 3944

2. Shubakara K, Umesha K B, Srikantamurthy $\mathrm{N}$ and Chethan J 2014 Antioxidant and DNA damage inhibition activities of 4-Aryl-N-(4-arylthiazol-
2-yl)-5,6-dihydro-4H-1,3,4-oxadiazine-2-carboxamides J. Chem. Sci. 1261913

3. Saundan A R, Yarlakatti M, Walmik P and Katkar V 2012 Synthesis, antioxidant and antimicrobial evaluation of thiazolidinone, azetidinone encompassing indolylthienopyrimidines J. Chem. Sci. 124469

4. Kathrotiya H G and Patel MP 2013 An efficient synthesis of 3-indolyl substituted pyrido[1,2- $a$ ]benzimidazoles as potential antimicrobial and antioxidant agents J. Chem. Sci. 125993

5. Herrera M B, Sayago A and Beltrán R 2017 Exploring antioxidant reactivity and molecular structure of phenols by means of two coupled assays using fluorescence probe (2,3-diazabicyclo[2.2.2] oct-2-ene, DBO) and free radical (2,2-diphenyl-1-picrylhydrazyl, DPPH) J. Chem. Sci. 1291381

6. Cimerman Z, Miljanic S and Galic N 2000 Schiff bases derived from aminopyridines as spectrofluorimetric analytical reagents Croat. Chem. Acta $\mathbf{7 3} 81$

7. Chandramouli C, Shivanand M R, Nayanbhai T B, Bheemachari B and Udupi R H 2012 Synthesis and biological screening of certain new triazole schiff's bases and their derivatives bearing substituted benzothiazole moiety J. Chem. Pharm. Res. 41151

8. Chinnasamy R P, Sundararajan R and Govindaraj S 2010 Synthesis, characterization, and analgesic activity of novel schiff base of isatin derivatives J. Adv. Pharm. Technol. Res. 1342

9. Venkatesh P 2011 Synthesis, characterization and antimicrobial activity of various schiff bases complexes of $\mathrm{Zn}$ (II) and $\mathrm{Cu}$ (II) ions Asian. J. Pharm. Health. Sci. 18

10. Chaubey A and Pandeya S N 2012 Synthesis and anticonvulsant activity (Chemo Shock) of Schiff and Mannich bases of Isatin derivatives with 2-Amino pyridine (mechanism of action) Int. J. Pharmtech. Res. 4590

11. Aboul-Fadl T, Mohammed F A and Hassan E A 2003 Synthesis, antitubercular activity and pharmacokinetic studies of some Schiff bases derived from 1-alkylisatin and isonicotinic acid hydrazide Arch. Pharm. Res. 26 778

12. Ali S M, Azad M A, Jesmin M, Ahsan S, Rahman M M, Khanam J A, Islam M N and Shahriar S M 2012 In vivo anticancer activity of vanillin semicarbazone Asian. Pac. J. Trop. Biomed. 2438

13. Wei D, Li N, Lu G and Yao K 2006 Synthesis, catalytic and biological activity of novel dinuclear copper complex with Schiff base Sci. China Ser. B 49225

14. Avaji P G, Vinod Kumar C H, Patil S A, Shivananda K N and Nagaraju C 2009 Synthesis, spectral characterization, in-vitro microbiological evaluation and cytotoxic activities of novel macrocyclic bishydrazone Eur. J. Med. Chem. 443552

15. Venugopala K N and Jayashree B S 2003 Synthesis of carboxamides of 2/-amino-4/-(6-bromo-3-coumarinyl) thiazole as analgesic and antiinflammatory agents Indian J. Heterocycl. Chem. 12307

16. Vashi K and Naik H B 2004 Synthesis of novel Schiff base and azetidinone derivatives and their antibacterial activity Eur. J. Chem. 1272

17. Dhar D N and Taploo C L 1982 Schiff bases and their applications J. Sci. Ind. Res. 41501 
18. Li S, Chen S, Lei S, Ma H, Yu R and Liu D 1999 Investigation on some Schiff bases as $\mathrm{HCl}$ corrosion inhibitors for copper Corros. Sci. 411273

19. Xavier A and Srividhya N 2014 Synthesis and study of Schiff base ligands IOSR J. Appl. Chem. 7 06

20. Worku D, Negussie M, Raju V J T, Negussie R, Solomon T, Jönsson J A and Negussie R 2003 Studies on transition metal complexes of herbicidal compounds
II: Transition metal complexes of derivatized 2-chloro-4ethylamino-6-isopropylamino-s-triazine (atrazine) Bull. Chem. Soc. Ethiop. 1735

21. Williams W B, Cuvelier M E and Berset C 1995 Use of a free radical method to evaluate antioxidant activity Lebensm.-Wiss.-Technol. 2825

22. Arnao M B, Cano A and Acosta M 2001 The hydrophilic and lipophilic contribution to total antioxidant activity Food Chem. 73239 